\title{
Suočavanje s krivnjom i sramom
}

\author{
JoSIP BOŠNJAKOVIĆ* \\ UDK: 159.942.52 • Pregledni članak \\ Primljeno: 4. siječnja 2017. • Prihvaćeno: 27. veljače 2017.
}

Sažetak: Prepoznavati osjećaje koji otežavaju uspostavljanje odnosa s drugima važno je za psihičko i duhovno blagostanje osobe jer kada se upoznamo s njima i postajemo svjesni kako utječu na život, moguće ih je mijenjati radi punijega odnosa s drugima. S tom nakanom u našem radu istražujemo složene osjećaje krivnje i srama, prepoznajući u njima potencijal za sazrijevanje osobe u odnosu prema sebi, drugima i Bogu. Oba osjećaja prisutna su od samih početaka pisane riječi o čovjeku, no njihova aktualnost $i$ danas ima svoje značenje u psihologiji i teologiji. I jedan i drugi značajno utječu na prekid odnosa, a odnos prepoznajemo kao temeljnu potrebu čovjeka kao društvenoga bića, te je stoga bitno vidjeti kako osobi pomoći u obnovi, kultiviranju i unaprjedivanju odnosa. Promišljali smo o tim dvjema stvarnostima kako bismo ponudili konkretne i specifične prijedloge u suočavanju i integriranju istih.

${ }^{*}$ Dr. sc. Josip

Bošnjaković, Katolički bogoslovni fakultet u Đakovu Sveučilišta

J. J. Strossmayera u Osijeku, P. Preradovića 17, 31400 Đakovo, Hrvatska; Hrvatsko katoličko sveučilište, Ilica 242, 10000

Zagreb, Hrvatska, jobosnjakovic@gmail. com

Ključne riječi: krivnja, sram, izolacija, odnos, blagoslov.

\section{Uvod}

Kada se po bibliografskim tražilicama istražuju znanstveni članci o pojmu krivnje i osjećaju krivnje, tada se, barem što se tiče psihologije, oni često vežu uz sram i osjećaj srama, pokušavajući diferencirati, razlikovati jednu od druge. Vrlo često krivnja i sram povezuju se i stavljaju jedno uz drugo, no da bismo razumjeli govor o krivnji i sramu čini nam se nužnim učiniti jasnu razliku između njih. Upravo stoga smo u našem članku krenuli od psihoanalitičkoga pogleda (S. Freud i E. H. Erikson) na krivnju i sram, da bismo potom izložili što je to krivnja, a što sram, kao pretpostavku mogućoj diferencijaciji krivnje i srama. Kada promišljamo o krivnji i sramu, tada je nužno reći da je riječ o unutarnjim procesima kroz koje osoba prolazi s obzirom na vlastito 
iskustvo odnosa prema sebi, ali isto tako i odnosa prema drugima i Bogu. I krivnja i sram osjećaji su koji su bitno povezani s drugima/Drugim. No u našem radu želimo dati i jedan pokušaj suočavanja s krivnjom i sramom s pomoću specifičnih procesa pretežito psihičke prirode, ali ćemo jasno naglasiti i važnost teološkoga elementa, napose kod oprosta i blagoslova.

\section{Razvojni pogled na krivnju i sram}

Krivnja i sram sastavni su dijelovi rasta i odgoja ne samo djeteta i adolescenta, što su napose osjetljiva razdoblja razvoja jednoga čovjeka, nego i odraslih te zrelih i starih ljudi. Svaki pojedinac na sebi svojstven način proživljavat će i te složene osjećaje ${ }^{1}$, no da bismo ih mogli općenito razumijevati, naše izlaganje započinjemo psihoanalitičkom teorijom S. Freuda i E. Eriksona ističući posebnosti jednoga i drugoga autora s obzirom na naš izbor teme rada.

\subsection{Sigmund FreUd I KRIVNJA}

Iz ranih Freudovih spisa uočavamo kako njegov psihoanalitički pogled stavlja naglasak na super-ego kada je riječ o krivnji i sramu². Super-ego se oblikuje od najranijega djetinjstva te čini dio cjelovitoga ega ${ }^{3}$, ali u sebi ima dimenziju normativnosti, savjesti ${ }^{4}$. Super-ego je internalizirana, pounutarnjena slika oca i majke ${ }^{5}$. Identifikacija je prvi izraz emotivne povezanosti s drugom osobom. Dijete se identificira s vlastitim roditeljima ili pak s jednim od njih, kao i s mogućom drugom primarnom figurom koja se brine o djetetu. Prvu sliku oca i majke koju dijete internalizira Goodwin ${ }^{6}$ nazi-

\footnotetext{
${ }^{1}$ Među autorima ne postoji ujednačeno mišljenje s obzirom na izraze osjećaji, emocije, afekti (Z. MILIVOJEVIĆ, Emocije, Zagreb, 2010.; B. PETZ, Uvod u Psihologiju, Jastrebarsko, 2010.; M. M. GOULDING, R. L. GOULDING, Il cambiamento di vita nella terapia ridecisionale, Roma, 1983. Kada govorimo o osjećajima, tada podrazumijevamo da je riječ o složenim biopsihičkim fenomenima koji u sebi imaju jednu objektivnu komponentu koja se odnosi na somatsku promjenu u ravnoteži organizma te subjektivnu komponentu intenzivnoga doživljaja ugode ili neugode (V. POLIZZI, Emozione/Emotività, u: J. M. PRELEZZO, C. NANNI, G. MALIZIA, Dizionario di scienze dell'educazione, Torini, 1997., 373.). Imajući u vidu tu široku definiciju osjećaja, prepoznajemo u njoj i osjećaje krivnje i srama te ćemo se prema njoj u našem radu ravnati.

2 P. A. HAZARD, Freud's Teaching on Shame, u: Laval théologique et philosophique 25(1969.)2, 234.267.

${ }^{3}$ Freud o strukturi ličnosti govori: »Prema tome, Nad-ja (Super-Ego), Ja i Ono tri su carstva, provincije, na koje razlažemo duševni aparat ličnosti.« (S. FROJD, Nova predavanja, Beograd, 1970., 162.-163.).

${ }^{4}$ S. FROJD, Nova predavanja, 145.-172.

${ }^{5}$ Isto, str. 151.

${ }^{6}$ A. GOODWIN, Freud and Erikson: Their Contributions to the Psychology of God-Image Formation, u: Pastoral Psychology 47(1998.)2, 97.
} 
va ocem osobne pretpovijesti. Otac osobne pretpovijesti govori nam kako u temelju toga argumenta leži najranije iskustvo i najduže predstavljanje oca koje se pojavljuje u djetinjstvu u procesu koji Freud naziva $\gg$ primarna identifikacija $\ll$.

Primarna identifikacija odnosi se na prvoga $\gg$ oca $\ll$ kojega Freud vidi u oba roditelja, kao i u ljubavi koja je između njih. Majčina želja za ocem, očevo ispunjene te želje i odnos između njih dvoje podržava dijete i osigurava prvo i prvotno iskustvo identifikacije u najranijim mjesecima života ${ }^{7}$. Dijete se identificira i s majkom is ocem. Ta primarna identifikacija temelj je za stvaranje »idealnog Ega « te je ujedno i temelj prve slike Boga ${ }^{8}$.

U tom smislu vrlo je značajno primijetiti kako se Bog objavljuje Mojsiju - Izl 3, 13-15:

Nato Mojsije reče Bogu: »Ako dođem k Izraelcima pa im kažem: 'Bog otaca vaših poslao me k vama', i oni me zapitaju: 'Kako mu je ime?' - što ću im odgovoriti? « »Ja sam koji jesam《, reče Bog Mojsiju. Onda nastavi: »Ovako kaži Izraelcima: 'Ja jesam' posla me k vama.« Dalje je Bog Mojsiju rekao: »Kaži Izraelcima ovako: 'Jahve, Bog vaših otaca, Bog Abrahamov, Bog Izakov i Bog Jakovljev, poslao me k vama.' To mi je ime dovijeka, tako će me zvati od koljena do koljena.«

Iskustvo Boga dakle ima dvostruku dimenziju, jednu koja se odnosi na vlastito iskustvo s Bogom: »Ja sam koji jesam «, dakle vrlo otvoreno, a zatim i drugu dimenziju, dimenziju koja ide preko onih koji odgajaju. »Mali dječak pokazuje posebno zanimanje za vlastitog oca. On želi rasti kao otac i biti kao otac, te zauzeti njegovo mjesto posvuda. Jednostavno možemo reći da mu je otac ideal. ${ }^{9}$

Teoretičari objektnih odnosa tumače kako unutarnja podjela u djetetu potječe od toga što je ono internaliziralo, pounutarnjilo majku koja je $\mathrm{u}$ isto vrijeme i dobra prema njemu, ali i zla (ne u moralnom smislu riječi, nego ne zadovoljava sve dje-

\footnotetext{
${ }^{7} \gg$ Identifikacija je vrlo važan oblik vezivanja za drugu osobu, verovatno najprvobitniji, a nije isto što je i izbor objekta. Razlika se može izraziti otprilike na sledeći način: Kada se dečak identifikuje sa ocem, on želi da bude kao otac; a kada ga učini objektom svog izbora, onda želi da ga ima, posjeduje. U prvom slučaju se njegovo ja menja po uzoru na oca; u drugom slučaju to nije potrebno. Identifikacija i izbor objekta su u velikoj meri međusobno nezavisni [... K Kad neki objekt izgubimo, ili moramo da ga napustimo, onda se dosta često obeštećujemo na taj način što se s njim identifikujemo, što ga u svome Ja ponovno izgrađujemo, tako da u tom slučaju izbor objekta u neku ruku regredira na identifikaciju.«(S. FROJD, Nova predavanja, 152.-153.).

${ }^{8}$ A. GOODWIN, Freud and Erikson: Their Contributions to the Psychology of God-Image Formation, 97.

${ }^{9}$ S. FREUD, Identification, u: J. STRACHEY (ur.), The standard edition of the complete psychological works of Sigmund Freud, sv. 18., Toronto, 1955., 105.-111., ovdje 105.
} 
tetove prohtjeve). Nakon što je idealizirao vlastitu majku, cijepanje sebstva $a^{10}$ postaje obrambeni mehanizam u djetetu kada otkrije da majka nije savršena. Cijepanje tako štiti internalizirani objekt koji je dobar od onoga zlog dijela koji se također otkriva u majci. Dijete ne želi odbaciti objekt koji ga također voli i koji se brine o njemu. Slijedom toga dijete cijepa u sebi i vlastito sebstvo jer se dijete vrlo blisko poistovjećuje, identificira, s vlastitom majkom. To znači da je pounutarnjeno prikazivanje dobroga vlastitoga sebstva izgrađeno na temelju dobroga iskustva s dobrom majkom, a zlo sebstvo na temelju lošega iskustva s lošom majkom ${ }^{11}$. Dakle, već od malena sebstvo je u sebi podijeljeno. Taj rascjep liječi se s vremenom ako dijete ne ostane fiksirano na toj razini vlastitoga razvoja ${ }^{12}$.

Dijete će trebati integrirati dva internalizirana objekta u jednu cjelinu koja predstavlja majku, ali i sebstvo u realnom obliku i kao dobro i kao zlo. Ta integracija pomaže djetetu da bude svjesno kako je ljutnja prema lošoj majci bila usmjerena i prema dobroj majci jer one u integriranoj inačici predstavljaju jednu te istu osobu.

Sjedinjene sebstva stvara grižnju savjesti ili primitivnu krivnju koja se smanjuje reparacijom (popravkom): dijete u mašti ili interakcijom $s$ majkom pokušava to popraviti i tako ublažava i iscjeljuje raniji bijes, krivnju i mržnju ${ }^{13}$. Ako ne dođe do sjedinjenja tih dvaju dijelova sebstva ${ }^{14}$, tada to može dovesti do teških psihičkih poteškoća kao što su poremećaji osobnosti, uključujući pri tome ponajviše narcizam i

\footnotetext{
$10 \gg$ Kao imenica označuje, u općenitom smislu, jedinstvo i totalitet pojedinačne osobnosti. Pojam sebstva uključuje i ono što je postalo objektom iskustva i ono što nije; drugim riječima, ono što još nije ušlo u područje iskustva. Pojam [...] se razvio u psihoanalizi pod utjecajem engleske škole $[\ldots]$ i američke Ego-psihologije, s različitim značenjima. [...] U duhu engleske škole, sebstvo (Self) predstavlja osobu ukoliko je ona područje psihičke aktivnosti u svojem totalitetu. Gledano sa stajališta američke Ego-psihologije, sebstvo je izjednačeno s objektom u koji pojedinac ulaže na narcistički način. Može se reći da je prikaz o sebstvu jedna konstrukcija našeg Ega.« M. MALDONATO (ur.), Dizionario di scienze psicologiche. Psicologia. Psichiatria. Psicoanalisi. Neuroscienze, Napulj, 2008., 539. U hrvatskom se jeziku koristi istoznačnicama self i sebstvo. Budući da je djelo The Analysis of Self H. Kohuta, jednoga od utemeljitelja psihologije sebstva, prevedeno na hrvatski jezik Analiza sebstva, Zagreb, 1990., mi ćemo se u našem radu koristiti hrvatskom riječju sebstvo.

${ }^{11}$ Ovdje spominjemo majku, no to se događa i s nekom drugom primarnom figurom koja je preuzela brigu o rastu djeteta, što danas može biti učestalija pojava u odrastanju nego u Freudovo vrijeme.

${ }^{12}$ S. FROJD, O seksualnoj teoriji, Beograd, 1970., 106.-118.

${ }^{13}$ P. C. VITZ, J. M. MEADE, Self-forgiveness in Psychology and Psychotherapy: A Critique, u: Journal of Religion and Health 50(2011.)2, 248.-263.

${ }^{14}$ Tako Freud ističe: »Ali glavni deo osećanja manje vrednosti potiče iz odnosa Ja prema svome Nadja, i predstavlja, isto tako ko i osećanje krivice, izraz nategnutosti među njima. Uopšte se osećaj manje vrednosti i osećanje krivice teško mogu razdvojiti. Možda bi bilo dobro ako bi se u osećanju krivice videla erotična dopuna moralnog osećanja manje vrednosti. Ovom pitanju pojmovnog razgraničavanja u psihoanalizi poklonili smo malo pažnje.« (S. FROJD, Nova predavanja, 155.).
} 
granični poremećaj osobnosti. Narcizam je poremećaj u kojem se osoba isključivo vrti oko sebe te nije u stanju istinski voljeti niti je integrirala dobro i zlo u sebi. Te osobe načelno su sklone ili sve idealizirati ili sve kritizirati. Kod njih ne postoji nekakav prostor za sredinu. Kod graničnoga poremećaja osobnosti riječ je pak o tome da osoba vrlo lako prelazi iz oduševljenja u očaj, i prema sebi i prema drugima. Tada se u terapiji redovito ide prema tomu da se klijent nauči (samo)prihvaćati ${ }^{15}$. Vrlo je značajno, kako Vitz primjećuje, da je iscjeljenje rascijepanoga sebstva moguće s pomoću sve više razvijane sposobnosti bebe/djeteta da gleda ponad/iznad sebe te da »prihvaća u samo sebe dobro iz vanjskog svijeta ${ }^{16}$. Prihvatiti dobro iz vanjskoga svijeta znači priznati i sebi da postoji nešto dobro izvan osobe te da ona nije središte svijeta. Idealni ego ili super-ego ima ulogu (samo)promatranja, moralne savjesti, cenzure snova, kao i glavnu ulogu u represiji, odnosno potiskivanju ${ }^{17}$.

Svjesni smo kako se čovjek može tek onda definirati kada je u odnosu s drugim osobama. Tako i dijete izgrađuje svoj identitet kada je u odnosu sa svojim roditeljima, a napose s vlastitom majkom koja je prvi objekt s kojim se dijete susreće, identificira te slijedom vremena i raznih okolnosti polako i izdiferencira, to jest postaje samostalno. Stoga je vrlo bitno tko je ta druga osoba pred kime se mi definiramo i kakav je njezin stav prema nama, upravo i onda kada se govori o krivnji i sramu.

\subsection{ERIK H. ERIKSON I PRVE TRI PSIHOSOCIJALNE FAZE RAZVOJA LIČNOSTI}

Ono što za svrhu ovoga rada te promišljanja o krivnji i sramu uzimamo u obzir jest psihosocijalni razvoj djeteta, također dio šire psihoanalitiče teorije, te se baziramo na istraživanju Erika H. Eriksona koji je proučavao razvoj čovjeka kroz osam susljednih perioda ${ }^{18}$. Naglasit ćemo glavne crte prvih triju faza jer se one odnose na temu našega istraživanja krivnje i srama:

a) Prva razvojna faza, prema Eriksonu, od rođenja do 18 mjeseci, jest faza u kojoj se dijete susreće s društvenom krizom povjerenja i nepovjerenja prema najbližima. Vrlina koju u tom razdoblju dijete razvija jest nada jer nailazi na osobe koje odgovaraju na njegove potrebe. Osnovno povjerenje elementaran je i uglavnom nesvjestan osjećaj sigurnosti i vjere u odrasle koje dijete ima na stupnju dojenčeta (tijekom prve godine života). Ako, stjecanjem nepovoljnih

\footnotetext{
${ }^{15}$ P. C. VITZ, J. M. MEADE, Self-forgiveness in Psychology and Psychotherapy: A Critique, 250.

${ }^{16}$ Isto, 251.

${ }^{17}$ S. FROJD, Nova predavanja, 156.

${ }^{18}$ E. H. ERIKSON, Identity: Youth and Crisis, New York, 1968., 109.; E. H. ERIKSON, Identity and the life cycle, u: Psychological Issues 1(1959.), 18.-171.
} 
okolnosti, dijete ne izgradi taj osjećaj, tada će se kod njega razviti osjećaj temeljnoga nepovjerenja, pesimizam i osjećaj napuštenosti ${ }^{19}$.

b) Druga faza života jest od 18 mjeseci do treće godine života i obilježena je krizom između autonomije i srama, sumnje. Vrlina karakteristična za to razdoblje života jest volja, želja. To je faza u kojoj dijete postaje autonomnije, već hoda i nije više u potpunosti ovisno o drugima. Kao što autonomija i ponos proizlaze iz osjećaja unutarnje dobrote, tako sumnja i sram potječu od osjećaja zloće. Osjećaj samokontrole bez gubitka samopoštovanja ontološki je izvor osjećaja slobode. Od neizbježnoga osjećaja gubitka samokontrole i roditeljskoga stava prevelike kontrole proistječe dugotrajna sklonost sumnji i sramu. Kvaliteta odnosa između djeteta i roditelja jest primaran faktor toga hoće li dijete razvijati osjećaj samopoštovanja i kompetencije ili osjećaj bespomoćnosti, povučenosti i srama. Sram se pojavljuje kada roditelji pribjegavaju ponižavanju ili zadirkivanju djeteta, što potiče dijete da odbaci želje i interese. Sumnja proistječe iz vanjske kontrole koja djetetu krade osjećaj učinkovitosti, da je ono sposobno kontrolirati samo sebe. Kao što vidimo, prema Eriksonu, prije se razvija sram od krivnje i ima dalekosežnije posljedice od krivnje, što odgovara i psihodinamičkom pristupu razvoja čovjeka u smislu da rana iskustva utječu na daljnji i sljedeći razvoj djeteta-čovjeka ${ }^{20}$.

c) Nakon te faze slijedi razdoblje od treće do šeste godine u kojem se dijete nalazi između inicijative i krivnje, a vrlina koja je karakteristična za tu fazu jest svrha, cilj. Erikson o ju naziva Play Age, doba igre ${ }^{21}$. Ta faza obilježena je krizom inicijative odnosno krivnje. Inicijativa dodaje autonomiji, dakle prijašnjoj fazi, kvalitetu pothvata, planiranja i postizanja ciljeva radi aktivnoga sudjelovanja u svijetu. $S$ druge strane jest krivnja i zakočenost djeteta. I ovdje uviđamo kako je riječ o procesu u odgoju jednoga djeteta. Erikson se zatim vraća na Platonov pogled na model prave zaigranosti koja je želja svih mladih stvorenja, i životinja i ljudi, a to je skok. Vjera i nada integralan su dio jednoga skoka.

Vidjet ćemo poslije kako je igra upravo bitna kao kontraindikator krivnje te i sam lijek za krivnju. Kako bi mogao dobro skočiti, prvo očima a zatim, kako slijedi i razvoj, i s udovima, osoba, dijete, prvo mora naučiti kako se odnositi prema podlozi kao odskočnoj dasci te kako se otporno i sigurno prizemljiti. To znači da treba testirati fleksibilnost koja je zadana granicama. Granice je moguće nadilaziti, ali, ipak, u isto vrijeme podlijegati sili gravitacije. Stoga gdje god prevladava igra, tamo postoji

\footnotetext{
${ }^{19}$ E. H. ERIKSON, Identitet $i$ životni ciklus, Beograd, 2008., 12.

${ }^{20}$ Isto, 12.-13.

${ }^{21}$ E. H. ERIKSON, Identity: Youth and Crisis, 109.
} 
element iznenađenja nadilazeći puko ponavljanje i običaje. Skočiti, pa i u najmanjoj mjeri, traži osjećaj temeljnoga povjerenja, kao i osjećaj životnosti, utemeljen u nadi. Slijedi da je skok u tijelu očitovanje radosnoga unutarnjega izraza i pokreta od majke prema ocu i ponovno nazad. To je skok povjerenja. I onda, iz sasvim nove pozicije, moguć je i drugi skok, naime uzbudljiv povratak majci, ali sada kao sasvim drugoj. Povjerenje, u svjetlu te formulacije dinamično izmjenične igre među majkom, ocem i sobom, jest jasni izraz separacije i povezanosti, nužnosti prijašnjega $i$ budućega, kao i statusa povjerenja kao razvojnoga postignuća ${ }^{22}$.

Otac je, prema Eriksonu, »proces «, osjećajno perceptivni tijek onoga što se događa između majke i oca i njihove željenosti jednoga prema drugom, proces u kojem i pri kojem sebstvo djeteta jest vrjednovano i potvrđeno. To znači da djetetov osjećaj bivstva kroz vlastito sebstvo u društvu izmjenične želje za Ti (otac i majka kao supružnici) jest realiziran i daje mu se na vrijednosti te je podržan tijekom izmjene osjećaja između oca i majke ${ }^{23}$. Dijete pri tome nije samo puki promatrač događanja između oca i majke nego i aktivni sudionik, preuzimajući inicijativu kako bi bilo sigurno da ono nije iz toga odnosa isključeno te ne osjećajući se posramljenim i krivim. Vjera i nada ključni su u preuzimanju takve inicijative. Vjera je sposobnost koja nadahnjuje preuzimanje inicijative i oslobađa od krivnje, dok je nada sposobnost i vrlina koja očekuje ishode i podržava autonomiju djeteta, što je u suprotnosti s posramljenošću.

\subsection{KaTEgorizaCiJA RAZLIČITIH OBLIKA KRIVNJE}

Nakon pogleda na nastanak krivnje kod S. Freuda te na krivnju i sram kako ih tumači E. H. Erikson usmjerit ćemo se na suvremenu definiciju krivnje i srama aktualnih autora.

Tilghman-Osborne, Cole i Felton ${ }^{24}$ kodirali su teoretske definicije krivnje prema 18 ključnih značajki koje ovdje slijedom nabrajamo da bismo potom donijeli i konačnu definiciju krivnje.

1. Razvojni ključ - od djece koja su tek prohodala, preko male djece, adolescenata, mladih pa do starih osoba svi prepoznaju kod sebe krivnju. Djeca od dvije godine prepoznaju kada su prekršili jednu normu.

\footnotetext{
${ }^{22}$ A. GOODWIN, Freud and Erikson: Their Contributions to the Psychology of God-Image Formation, 105.

${ }^{23}$ Isto, 104.

${ }^{24}$ C. TILGHMAN-OSBORNE, D. A COLE, J. W. FELTON, Definition and measurement of guilt: Implications for clinical research and practice, u: Clinical Psychological Review 30(2010.), 536.-546.
} 
2. Moralni prekršaj - odnosi se na pojedinca o kojem se promišlja da je svjestan kako je prekršio nekakav moralni kodeks.

3. Socijalni prekršaj - odnosi se na izvršeni ili percipirani prekršaj društvenih normi. To znači da je na neki način načinio zlo drugima, što može biti obitelj, društvo ili netko treći.

4. Usredotočenost na sebstvo - odnosi se na krivnju u kojoj je osjećaj sebstva objekt iskustva krivnje. Ono se odnosi na sebstvo, sliku o sebi, vlastiti identitet.

5. Ne sebstvo - odnosi se na krivnju u kojoj je sebstvo eksplicitno isključeno od takvoga iskustva. Dakle, ovdje se osjećaj krivnje ni na koji način ne povezuje sa sobom i vlastitim sebstvom.

6. Javno/drugi - svojstvo je ove krivnje u tome da ona u sebi uključuje realno ili imaginativno postojanje drugih. Središnja točka toga promišljanja o krivnji odnosi se na postojanje drugih ili što drugi misle.

7. Ne javno / Ne drugi - ona je suprotnost od Javno/drugi čije je svojstvo u tome da nema prisutnosti, realne ili imaginativne, drugih ljudi. Krivnja je privatno iskustvo koje ne uključuje druge ili što bi oni mogli misliti.

8. Ponašanja/aktivnost - onaj vid krivnje kod kojega se definicija usmjerava $\mathrm{k}$ ponašanju, aktivnosti ili propustu. Taj je vid krivnje često polemiziran pod vidom čina ili propusta.

9. Prilagodba - onaj vid krivnje kod kojega autori eksplicitno tvrde da je krivnja pozitivan konstrukt koji vodi pozitivnim učincima i dobroj prilagodbi. To je u slučaju kada krivnja potiče osobu da izbjegava slična djelovanja u budućnosti, a da se usmjeri onim djelovanjima koja je izgrađuju.

10. Neprilagodba - odnosi se na karakteristiku krivnje kao negativnoga konstrukta što vodi problematičnim rezultatima. Neprilagođena krivnja uključuje procese koji ograničavaju motivaciju na negativna djelovanja.

11. Kajanja/Isprika - uključuje ideju kako krivnja potiče na ispriku ili kajanje. U tom je slučaju krivnja obilježena žaljenjem i tugom. Netko može žaliti zbog misli, osjećaja ili nekih čina.

12. Popravak - odnosi se na potrebu ili motivaciju popraviti, ispraviti ono što je učinjeno krivo. Iskusiti taj vid krivnje znači osjetiti potrebu popraviti štetu.

13. Crta ličnosti - odnosi se na poimanje u kojem je krivnja izražena načinom postojanja osobe, kronično ili karakterološki. Ta nam definicija ukazuje da se krivnja pojavljuje često kod osoba i gotovo u svim životnim situacijama. Riječ je o kroničnom iskustvu (npr. osobe koje imaju poteškoća sa skrupuloznošću). 
14. Krivnja - Specifična kada se odnosi na određene situacije u jednom vremenskom razdoblju. Često je definirana kao prijelazno iskustvo koje se ne može generalizirati na cijeli život (npr. ljubavnica, dvostruki stil života).

15. Krivnja - kao Bolno iskustvo govori nam da je riječ o nelagodnom doživljaju, pa i na tjelesnoj razini.

16. Odgovornost - To je središnji dio krivnje kada u definiciji promišljamo o percepciji onoga tko je vlasnik krivnje. Taj osjećaj odgovornosti ne mora biti vjerodostojan i smislen za druge. Nevjerodostojnost ili nevjerojatnost krivnje imamo kada se djeca osjećaju krivima zbog rastave vlastitih roditelja. To su osjećaji koji su povezani s vlastitom odgovornošću.

17. Podtip je oblik krivnje kada u definiciji uključuje nekakav poseban oblik krivnje. Može se odnositi na događaje, osjećaje ili karakteristike osobnosti. Primjeri takvoga oblika krivnje jesu na području spolnosti, osjećaja onoga koji je preživio neku situaciju a drugi nisu (rat, prometna nesreća), krivnja razvoda, krivnja svemoći, itd.

18. Druge specifične karakteristike - odnosi se na druga bitna svojstva koja se odnose na samo neke definicije, a ne mogu se smjestiti negdje dalje. Primjer toga može biti inhibicija ili strah od kazne (npr. strah od pakla).

S ključem od 18 mogućnosti autori ${ }^{25}$ su istraživali kako definirati krivnju te su je opisivali na sljedeći način: uključuje moralne i kognitivne elemente, prekršaj moralnih normi (realnih ili zamišljenih) pri kojem ljudi vjeruju da njihovi čini (ili propusti) dovode do negativnih ishoda. Nadalje, njihovo istraživanje otkrilo je poveznicu izmedu krivnje i morala, kao i (samo)optuživanja. Osjećaj odgovornosti i bolni osjećaj žaljenja također su dio iskustva krivnje. Ispaštanje ili popravak štete sekundaran je element krivnje koji ne ulazi izravno u definiciju, kao ni osobne karakteristike pojedinca. Krivnja nije crta ličnosti, nego skup misli i osjećaja koji se pojavljuju kao odgovor na specifične okolnosti, a mogu biti povezani s karakteristikama osobnosti i situacije. I kao zadnju misao u definiciji krivnje autori govore da ona u sebi uključuje (samo)optuživanje zbog nekoga ponašanja, ali ne i zbog osobina sebstva, to jest osobnosti. Kod krivnje se pojedinci okrivljuju jesu li ili nisu nešto učinili. Krivnja dakle ne uključuje opću karakteristiku (samo)optuživanja, što je više središnji dio srama, o čemu ćemo promišljati u jednom od sljedećih podnaslova. Autori toga istraživanja ipak naglašavaju kako pojam krivnje nije jednak na Istoku i Zapadu, to jest razlikuje se od kulture do kulture. Također smatraju da sociološki, filozofski i psihološki pogled mogu obogatiti pogled na krivnju.

${ }^{25}$ Isto, str. 544. 


\subsection{VJERA U BOGA ILI VLASTITI IDOLI ČINE DA SE OSJEĆAMO KRIVIMA}

Poseban oblik krivnje jest i onaj koji se rađa u odnosu s Bogom. Upravo taj odnos trebao bi biti čimbenik koji doprinosi mentalnom zdravlju osobe, odnosno, bolje rečeno, ima za posljedicu mentalno zdravlje ${ }^{26}$. S psihološke strane mogu se promatrati posljedice odnosa s Bogom, ali pri tome, naravno, da se ne tumači kakav je Bog. Stoga psihologija ne će poticati ljude da budu religiozni jer će im tada biti bolje. To nije njezina svrha ni cilj njezina proučavanja. No posljedice odnosa s Bogom moguće je proučavati. Svjesni smo kako se na temelju odnosa Bog - čovjek mogu graditi konstruktivni životi, ali isto tako i oni destruktivni. Na primjer, ako osoba prije svega vidi Boga kao Sudca, kao onoga koji kažnjava, razine tjeskobe i straha povećavaju se te ujedno i vlastita nesigurnost i osjećaj izgubljenosti, čineći pri tome da ionako slaba struktura osobnosti bude uzdrmana ${ }^{27}$. Nije li to ponekada prisutno i kod vjernika koji se boje Boga, pakla ili čak nije li to situacija i kada se straši ljude ili djecu Bogom: Bog sve vidi, Bog sve zna, sakrit mu se ništa ne da. Boga će te karati. Gorjet ćeš u paklu... Koliko te riječi pomažu u izgradnji odnosa povjerenja prema Bogu, a koliko ga, zapravo, i otežavaju stvarajući osjećaj krivnje? (Samo)optužba je grijeh zbog čega nam je potrebno Božje oproštenje. Na poseban način ne treba se optuživati ako je netko pogriješio u ostvarenju vlastitih visokih standarda moralnoga života, standarda koji si je osoba sama postavila. Moralni perfekcionizam nema mjesta u razumijevanju samoga sebe kao kršćanina.

Također, nismo pozvani stvarati nutarnje idole, među kojima može biti i želja biti savršen, ne griješiti. Prisutnost tako zahtjevnoga morala ili društvenih idola znak je oholosti koja ima potrebu za Božjim oproštenjem ili oproštenjem drugih ljudi koji su bili povrijeđeni društvenim idolima u životu jednoga vjernika. $\mathrm{Ne}$ (samo) oproštenje, nego (samo)prihvaćanje i poniznost mogu osloboditi osobu od tih negativnih osjećaja. Često dakle jedan vjernik ima potrebu iskočiti od nesvjesne (samo)pravedne/(samo)opravdavajuće moralne superiornosti koja mu onemogućuje prihvatiti oproštenje od Boga i od drugih ${ }^{28}$. Ima potrebu iskočiti jer neodržavanjem visoke ljestvice moralnih vrednota osoba počinje samu sebe okrivljavati i obezvrjeđivati.

Ako osoba ima crte ličnosti koje su na poseban način ranjive s obzirom na određeni vid življenja vlastite religioznosti, povećava se rizik, kao i razina, težega psihičkoga

\footnotetext{
${ }^{26}$ J. J. EXLINE, A. M. YALI, W. C. SANDERSON, Guilt, Discord, and Alienation: The Role of Religious Strain in Depression and Suicidality, u: Journal of Clinical Psychology 56(2000.)12, 1481.1496.

${ }^{27}$ G. F. POLI, G. CREA, Il tarlo che non consuma. Persone consacrate e fede in tempo di crisi, Roma, 2014.

${ }^{28}$ C. VITZ, J. M. MEADE, Self-forgiveness in Psychology and Psychotherapy: A Critique, 256.
} 
stanja. Tako npr. osobe koje imaju opsesivno-kompulzivne crte ličnosti, a izrazito su religiozne, sklone su pretjeranom isticanju i obavljanju religioznih obreda, pristupanju sakramentima. Time se utječe ne samo na religioznosti nego se i kompulzivnim ponavljanjem obrednih radnji može pogoršati psihičko stanje osobe. $U$ takvim situacijama doktrina Crkve može znatno utjecati na osjećaj krivnje i na strah te se osoba time osjeća pritisnuta i smanjuje joj se kvalitetu života ili se pak utječe na redovito funkcioniranje osobe, dok umjereni strah koji se može pojaviti kod religioznih ljudi može biti prevencija zastranjenja, ali može i potaknuti osobu na prosocijalno djelovanje $\mathrm{e}^{29}$. Stoga je vrlo bitno uočiti kakve slike o Bogu ima pojedina osoba.

\subsection{SRAM}

Lewis ${ }^{30}$ je prva od psihoanalitičkih autora koja se detaljnije pozabavila sramom u vidu kliničke prakse. Ona je naglašavala borbu i nastojanje oko povratka osjećaja vrijednosti koji se izgubio i u odnosu drugih prema osobi i u odnosu osobe prema samoj sebi, na što ćemo upozoriti i kod biblijsko-teološkoga vida srama s prve stranice Biblije. Wurmser ${ }^{31}$ opisuje sram povezujući ga s vjerovanjem da nešto nije u redu sa mnom koje osoba proživljava pripisujući si ujedno etikete: slab sam, prljav sam, pokvaren. Basch ${ }^{32}$ je sramu dao vrlo značajno mjesto u psihoanalitičkoj teoriji sebstva te opisuje sram kao »bolnu emociju ... temeljno zaštitničkog karaktera « koja je pak povezana s prekidom (samo)izražavanja i očekivanja. Kohut ${ }^{33}$ i Morrison $^{34}$ vide korijen srama u iskustvu nedostatka empatije u sadašnjem životu te isto tako u osjećaju nesigurnosti koji je plod uskraćenoga empatijskoga pristupa roditelja u ranom djetinjstvu. English ${ }^{35} 1975$. godine piše kako je sram daleko arhaičnije iskustvo nego krivnja te da je sram, za razliku od krivnje, više vezan uz fiziološke reakcije pri čemu osoba osjeća kako srce počinje brže kucati, kako se crveni, mijenja se ritam disanja, osoba se osjeća ograničena u vlastitom govoru, nesigurna u samu sebe. Biti posramljen znači imati i psihosomatsku reakciju.

${ }^{29}$ G. F. POLI, G. CREA, Il tarlo che non consuma. Persone consacrate e fede in tempo di crisi, 192.

${ }^{30}$ H. B. LEWIS, Shame and guilt in neurosis, New York, 1971. Freud se više bavio temom krivnje, a manje temom srama, te stoga spominjemo Lewis kao jednu od prvih psihoanalitičarki koja proučava pojam srama.

${ }^{31}$ L. WURMSER, Shame-the veiled companion of narcissism, u: D. L. NATHANSON (ur.), The many faces of shame, New York, 1987., 27.-28.

${ }^{32}$ M. BASCH, Understanding psychotherapy, New York, 1988., 136.

${ }^{33}$ H. KOHUT, The restoration of the self, New York, 1977.

${ }^{34}$ A. P. MORRISON, The eye tuned inward: Shame and the self, u: D. L. NATHANSON (ur.), The many faces of shame, New York, 1987., 271.-291.

${ }^{35}$ F. ENGLISH, Shame and Social Control, u: Transactional Analysis Journal 5(1975.)1, 24.-28. 
Govoreći o psihosocijalnom razvoju djeteta prema Eriksonu, već smo spomenuli u kojem se razdoblju života počinje razvijati sram, to jest u drugoj godini života. $\mathrm{Na}$ poseban način sram se ponovno aktualizira u jednom od glavnih stadija razvoja, to jest $\mathrm{u}$ adolescenciji, koja se, prema mnogima, naziva i vremenom drugoga rođenja, a Erikson to razdoblje naziva vremenom definiranja vlastitoga identiteta. Rast $\mathrm{u}$ adolescenciji, koji je često nemiran i neharmoničan, popraćen raznim izazovima, u svojim početnim fazama dovodi adolescenta do toga da živi u stalnom osjećaju neprimjerenosti, neprilagođenosti i sramote u odnosu na druge. Posljedica je toga da adolescent razvija negativnu sliku o sebi, da se osjeća podređeno, posebno kad je riječ o tijelu ${ }^{36}$. U tom smislu biti viđen gol već izaziva osjećaj stida i srama ${ }^{37}$.

Gledajući s biblijsko-teološkoga stajališta, sram je posljedica čovjekova nasjedanja na zmijinu prijevaru što je dovelo do poremećaja međusobnih odnosa koji je urodio strahom od tuđega pogleda ${ }^{38}$. Tako D. Runje sažima sram s biblijskoga gledišta. Osoba se skriva od pogleda, i od Boga i od drugih, ali i sama od sebe. Stoga je iskustvo srama vrlo bolno i osoba u takvom stanju osjeća i doživljava određeni unutarnji rascjep. Vrlo je značajno spomenuti i daljnje promišljanje D. Runje na tragu svetopisamskoga teksta Post 2, 25 gdje se ističe kako se Adam i Eva nisu sramili samih sebe jedno prema drugom, nego i prema trećim osobama, ali i Bogu ${ }^{39}$.

Značajno je nadalje primijetiti da su se Adam i Eva sakrili kada su se postidjeli. Često je sram povezan s osjećajem straha ${ }^{40}$. Potreba da se spusti pogled iskaz je

\footnotetext{
${ }^{36}$ S. TOGNACCI, Psihologija srama: glavni psihologijski i kulturološki vidovi, u: Crkva u svijetu 51(2016.)3, 455.
}

${ }^{37}$ Spomenimo kako se osjećaj stida, za razliku od srama, odnosi na spolni život ljudi te da su ljudi napose osjetljivi kada je spolnost u pitanju. U našem radu zaustavit ćemo se na promišljanju o sramu, ne ulazeći dublje u razlikovanje srama i stida.

${ }^{38}$ D. RUNJE, Stid u Post 2, 25 - 3, 21, u: Crkva u svijetu 51(2016.)3, 396.-412.

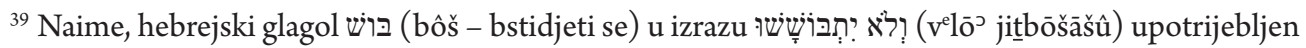
je u trećem licu množine imperfekta hitpolela. Hitpolel je intenzivna refleksivno-recipročna hebrejska konjugacija koja izražava međusobni odnos subjekata u rečenici. Zato je prijevod: »nisu se stidjeli jedno pred drugim «, bolji, a još precizniji prijevod bio bi: »nisu se stidjeli jedno drugoga.« Na taj je način govor o izostanku stida potpun. Hoće se reći kako se čovjek i njegova žena nisu stidjeli ni samih sebe jedno pred drugim ni jedno drugoga pred trećom osobom. U tom je slučaju treća osoba Bog, ali i lukava zmija pred kojom prije kršenja Božje zapovijedi čovjek i njegova žena također nisu osjećali stid zbog toga što su goli. Osjećaj stida nije postojao ni u kakvom obliku. To znači da stid nije predosjećaj, nego osjećaj koji se temelji na nekom prethodnom događaju i činjenici. Prema tomu, biti gol nije uzrok stida, nego stid dolazi kao posljedica nečega što mijenja odnos prema golom tijelu. Prije nečega takvoga ni muškarac ni žena nisu osjećali potrebu da pokriju ni vlastitu ni tuđu golotinju (D. RUNJE, Stid u Post 2, 25 - 3, 21, 396.-412.).

40 »Bože moj! Stid me i bojim se podići svoje lice k tebi, Bože moj! Jer su se umnožila zlodjela naša preko glave i grijesi su se naši nagomilali do neba.« $($ Ezr 9, 6). 
želje »psihološkog distanciranja od drugih «, udaljavanje od mogućega pogleda u trenutku kada osoba ne želi biti viđena. ${ }^{4}$ Sram se rađa kad u javnosti izgubimo sliku koju smo imali o sebi te, iako se može govoriti i o drugim vidovima, taj vid predstavlja središnji dio osjećaja srama. ${ }^{42}$ Sram proizlazi iz gubitka odgovarajuće slike o sebi u javnosti i gubitka samopoštovanja, samovrjednovanja, što utječe zatim na $\gg$ kompleks manje vrijednosti « te ugrožava identitet osobe. Kada je narušena slika o sebi, osjećaj srama koji se javlja izuzetno je snažan te osoba pati ${ }^{43}$.

Kod srama, prema Erskinu, osoba ima uvjerenje o sebi: $\gg$ Sa mnom nešto nije u redu «, te je to plod poruka i odluka, zaključaka donesenih na temelju nemogućih zahtjeva od primarnih osoba koje su se brinule o rastu jednoga djeteta te također na temelju pretjerane kontrole. Nadalje, sram uključuje u sebi vrlo nisko samopoštovanje, što smo već vidjeli, povezano s kriticizmom, obrambenim stavom tuge i straha, te ujedno i nesvjesnom ljutnjom. Plod svega toga jest inhibiranost, zakočenost osobe, ograničenost i kontrola istraživačke znatiželje ${ }^{44}$.

Goldberg pak tvrdi kako je sram posljedica gubitka povezanosti sa značajnom, brižnom i voljenom osobom koja je, ili se pak vjeruje da jest, nužna za psihološko i fiziološko preživljavanje. Rezultat toga je, kako je već spomenuto, gubitak samopoštovanja te se osoba počinje skrivati štiteći se tako od mogućih ponižavanja i prijekora drugih u budućnosti ${ }^{45}$. U tom smislu sram ima i ulogu obrambenoga mehanizma što i Erskine ${ }^{46}$ ističe govoreći kako je sram samozaštitnički proces kojim se koristi kako bi se izbjegli osjećaji ponižavanja i ranjivosti koji se rađaju u gubitku kontakta i odnosa s drugim osobama.

\section{Diferencijacija krivnje i srama}

Kako bismo pojasnili osnovnu razliku između krivnje i srama sažimamo prvo što je to krivnja, a što sram. Jedna od najjednostavnijih definicija krivnje jest da je negativan osjećaj i vjerovanje da je osoba odgovorna za određene posljedice. ${ }^{47}$ Krivnja

\footnotetext{
${ }^{41}$ L. ANOLLI, La Vergogna. Quando la nostra immagine va in frantumi, Bologna, 2010., 57.

${ }^{42}$ Isto, str. 23.

${ }^{43}$ S. TOGNACCI, Psihologija srama: glavni psihologijski i kulturološki vidovi, 453.-477.

${ }^{44}$ R. G. ERSKINE, Shame and Self-Righteousness: Transactional Analysis Perspectives and Clinical Interventions, u: Transactional Analysis Journal 24(1994.)2, 87.

${ }^{45}$ C. GOLDBERG, The role of existential shame in the healing endeavor, u: Psychotherapy 27(1990.)4, 591.-599.

${ }^{46}$ R. G. ERSKINE, Shame and Self-Righteousness: Transactional Analysis Perspectives and Clinical Interventions, 90.

${ }^{47}$ K. C. BARRETT, C. ZAHN-WAXLER, P. M. COLE, Avoiders vs. amenders: Implications for the investigation of guilt and shame during toddlerhood, u: Cognition and Emotion 7(1993.), 481.-505.
} 
postaje teža onda kada se čin ili djelo ne mogu ispraviti. Sram je pak, kako smo vidjeli, više bolno i razarajuće iskustvo. ${ }^{48} \mathrm{Kod}$ srama je objekt cijela osoba, sebstvo. Loša stvar izražava se kao promišljanje o lošem sebstu, samome sebi, te bol zahvaća cijelo biće. Osoba se osjeća maleno, bezvrijedno i bespomoćno. Sram također potiče osjećaj izloženosti u smislu izloženosti pred drugima. Lewis ${ }^{49}$ je tvrdila kako se sram više odnosi na afektivne poremećaje, dok se krivnja odnosi na kognitivne. Ona to tumači činjenicom da će osobe koje imaju neintegrirano sebstvo, dakle imaju više poteškoća u viđenju sebe kao autonomnih osoba, češće osjećati sram, dok će osobe koje imaju integrirano sebstvo, vlastitu osobnost, češće doživljavati krivnju jer razlikuju sebe od svojih ponašanja.

I sram i krivnju s psihoanalitičkoga pogleda smještamo u vlastitosti super-ega, to jest onoga dijela sebstva koji ima normativni, zapovjedni, karakter. Krivnja je više pozitivan učinak super-ega. Krivnja potiče prosocijalno, ispravljujuće ponašanje, kao i empatiju te ima malu ili gotovo nikakvu poveznicu s psihopatologijom. Sram, i na interpersonalnoj, međuljudskoj, i na intrapersonalnoj razini, unutar same osobe, ima loš utjecaj na prilagodbu, ponajviše zbog toga što osoba općenito negativno vrjednuje samu sebe te je sram također povezan s osjećajem gubitka kontrole. Nadalje je u pozitivnoj korelaciji s agresivnošću, s nedostatkom empatije na interpersonalnoj razini te različitim psihičkim simptomima, među kojima ističemo depresiju, tjeskobu i strah ${ }^{50}$.

Psihoanalitički orijentirani psiholozi prepoznali su u sramu ključ depresivnosti, bipolarnih poremećaja, shizofrenije i narcisoidnosti ${ }^{51}$. Sram se dakle odnosi na osjećaje bezvrijednosti ili zloće ne zbog nekoga specifičnoga i pojedinoga čina, nego radije zbog toga što osoba osjeća ili doživljava da je ona u sebi zla ili neprikladna ili iznutra nevrijedna ${ }^{52}$. Osjećaj srama, kako smo naglasili, često ima svoje uzroke u roditeljskoj kritici, odbijanju ili zlostavljanju. Stoga ona osoba koja se osjeća krivom manje je demoralizirana i oslabljena od osobe koja se srami ili se osjeća posramljenom. Jednostavno rečeno, netko može misliti da je učinio nešto loše, iako je dobra osoba. Osoba koja je pogriješila više je u mogućnosti promišljati kako je njezin čin

\footnotetext{
${ }^{48}$ J. P. TANGNEY, P. WAGNER, R. GRAMZOW, Proneness to Shame, Proneness to Guilt, and Psychopathology, u: Jorunal of Abnormal Psychology 101(1992.)3, 469.-478.

${ }^{49}$ H. B. LEWIS, Shame and guilt in neurosis, New York, 1971.

${ }^{50}$ P. LUYTEN, J. COVELEYN, J. R. J. FONTAINE, The relationship between religiosity and mental health: distinguishing between shame and guilt, u: Mental Health, Religion \& Culture 1(1998.)2, 166.-167.

${ }^{51}$ J. P. TANGNEY, P. WAGNER, R. GRAMZOW, Proneness to Shame, Proneness to Guilt, and Psychopathology, 470.

${ }^{52}$ C. VITZ, J. M. MEADE, Self-forgiveness in Psychology and Psychotherapy: A Critique, 258.
} 
utjecao na druge osobe, te stoga pojedina istraživanja tvrde kako su one osobe koje se osjećaju krivima sposobnije za empatiju od onih koje se srame ${ }^{53}$.

Hoffman je tvrdio kako se osjećaj krivnje može javiti u empatijskom doživljavanju druge osobe jer osoba uzima gledište promatranja onoga kome je nanijela zlo. Daljnja istraživanja pak govore kako se osoba može osjećati krivom zbog svijesti da bi mogla izgubiti određene veze s drugima jer se zbog njezinih loših ili zlih čina drugi mogu od nje udaljiti, te je stoga povezana s empatijom ${ }^{54}$. Sram je pak u gotovo svim istraživanjima negativno povezan $\mathrm{s}$ empatijom jer kod srama osoba ima negativan stav o sebi te vrlo nisko samopoštovanje. Osoba koja se srami ima poteškoću razumijevati svijet druge osobe, gotovo poteškoću maknuti se od same sebe. Jedno daljnje istraživanje ${ }^{55}$, na tragu spomenutoga, ističe kako se religiozni ljudi više osjećaju krivima, te stoga više pokazuju i empatiju prema drugima.

Ovdje govorimo o umjerenom osjećaju krivnje. Izrazito naglašen osjećaj krivnje povezan je s psihičkim poteškoćama ${ }^{56}$. Stoga je značajno primijetiti i razlikovati osjećaj krivnje s obzirom na situaciju, okolnosti i težinu, o čemu smo više pisali kada smo promišljali o krivnji. Neprimjerena krivnja znači zaokupljenost ili predbacivanje zbog manjih pogrješaka s naznakom da tada ljudi imaju prekomjeran osjećaj odgovornosti za nezgode koje se događaju. Tako se npr. netko može osjećati krivim zbog nečega nad čim uopće nema kontrolu. Nekorektno preuzimanje odgovornosti za negativna događanja čini jedan od kognitivnih problema koji je često povezan $\mathrm{s}$ depresivnošću. Istraživanja ${ }^{57}$ pokazuju kako neprilagođena i pretjerana krivnja $\mathrm{s}$ vremenom postaje sve manje normativnoga karaktera, a sve više potiče depresivna raspoloženja. Načelno govoreći, krivnja pretpostavlja da je netko učinio određeni čin, pa zbog toga treba biti proglašen krivim ili se osoba sama osjeća krivom zbog toga što je prekršila neku vlastitu normu. Osjećaj krivnje otežava osobi živjeti u slobodi te osjećaj krivnje crpi i dosta energije od osobe. Kod osjećaja krivnje osoba se zatim zaustavlja kod same sebe i vrti u krug.

${ }^{53}$ K. P. LEITH, R. F. BAUMEISTER, Empathy, Shame, Guilt, and Narratives of Interpersonal Conflicts: Guilt-Prone People Are Better at Perspective Taking, u: Journal of Personality 66(1988.), 3.

${ }^{54}$ Isto, 6.

${ }^{55}$ P. LUYTEN, J. COVELEYN, J. R. J. FONTAINE, The relationship between religiosity and mental health: distinguishing between shame and guilt, 165.-184.

${ }^{56}$ Isto, 167.

${ }^{57}$ C. TILGHMAN-OSBORNE, D. A. COLE, JULIA W. FELTON, Inappropriate and Excessive Guilt: Instrument Validation and Developmental Differences in Relation to Depression, u: Journal of Abnormal Child Psychology 40(2012.), 607.-620. 
Krivnja se povezuje uz moralno promišljanje i ponašanje $\mathrm{e}^{58}$. Mnogi je povezuju uz depresivnost, opsesivno-kompulzivni poremećaj, anksioznost, somatizaciju i psihozu. Neki daju i pozitivnu vrijednost krivnji jer ona potiče osobu ili društvo na popravljanje/ispravak, kao i na iskupljenje, te se osoba angažira u tom smjeru. $\mathrm{Na}$ kojim moralnim načelima temeljimo naše odluke u životu utjecat će i na osjećaj krivnje. Ako zastanemo kako bismo o tome razmislili, iskustvo će nam reći da se ljudi jako razlikuju s obzirom na moralnost svojih misli i akcija. Psiholozi moral općenito definiraju kao stavove i vjerovanja ljudi koja im pomažu u odlučivanju što je dobro, a što loše. Pojam morala određen je pravilima i normama vladanja koje su zadane kulturom u kojoj smo odrasli, koju smo internalizirali. Moral nije dio standardne opreme s kojom smo došli na svijet. Rođeni smo bez morala, tvrdi Kohlberg, utjecajni istraživač psihologije razvoja moralnoga života ${ }^{59}$. Tijekom našega razvoja u djetinjstvu, adolescenciji i odrasloj dobi stekli smo pojam dobroga i lošega.

Istaknuli smo pozitivan vid krivnje, te stoga želimo istaknuti i pozitivan vid srama jer je očito da i sram ima određenu ulogu u životu pojedinca. Naime, sram i samopravednost jesu zaštitnički mehanizmi koji pomažu osobi da izbjegne ranjivost ponižavanja, kao i gubitak kontakta u odnosu. Kada je odnos otežan kritiziranjem, ismijavanjem, ponižavanjem, ignoriranjem ili drugim ponižavajućim ponašanjem, rezultat je onda povećana ranjivost u međuljudskim odnosima. Kontakt privrženosti prekinut je. Sram i samopravednost rezultat su zlobnoga ponižavanja i prigovaranja, kao i gubitka samopoštovanja. Oboje su, i sram i samopravednost, odraz obrane kojom se koristi kako bi se izbjeglo upečatljivo iskustvo koliko se ranjivo i bespomoćno pojedinac osjeća kada izgubi kontakt $s$ drugima ${ }^{60}$. U tome smislu osoba zadržava bilo kakav kontakt i radije živi u težem odnosu nego bez ikakvoga kontakta i odnosa. U isto vrijeme sram je izraz nesvjesne nade da će druga osoba preuzeti odgovornost kako bi se ispravio procjep koji je nastao u odnosu. Sram je složen proces koji u sebi uključuje: a) umanjenu svijest o sebi, nisko samopouzdanje u odnosu s vanjskim ponižavanjem i/ili internaliziranim okrivljavanjem; b) obrambeno prenošenje tuge i straha; c) negiranje bijesa. Sram uključuje poricanje bijesa kako bi se sačuvala vanjština održanoga odnosa s osobom koja je uključena u ponižavajuće transakcije. Kada se poriče bijes, vrijednosni je vid sebstva izgubljen. Karakteristika sebstva jedne osobe jest da je željno biti ozbiljno i s poštovanjem shvaćeno te da ujedno ima potrebu ostaviti dojam na druge. Kada je dijete poniže-

${ }^{58}$ Isto, 607.-620.

${ }^{59}$ L. KOHLBERG, Razvoj dječje orijentacije prema moralnom poretku: slijed u razvoju moralnog mišljenja, u: Vita Humana 6(1963.), 11.-33.

${ }^{60}$ R. ERSKINE, Shame and Self-Righteousness: Transactional Analysis Perspectives and Clinical Interventions, u: R. G. ERSKINE, Theories and methods of an integrative transactional analysis: A volume of selected articles, San Francisco, 1980., 46.-67. 
no, strah od gubitka odnosa i tuga zbog neprihvaćanja preobražavaju se u osjećaj srama $^{61}$.

Sram usmjerava svoju pozornost na to kako drugi prosuđuju onoga tko se srami, dakle usmjerava pozornost na svoje sebstvo/jastvo. Krivnja pak premješta pozornost na drugoga prema kojemu je bila ostvarena nekakva djelatnost koja će zahtijevati da bude ispravljena, obnovljena kako bi se opet zadobio odnos ili povjerenje koji su bili prekinuti ili oštećeni. K tomu, sram je neugodan i stvara osjećaj okaljanosti, neprimjerenosti, dok krivnja dopušta veću mogućnost popravljanja stanja i ima jednu empatičnu dimenziju koja se ne smanjuje. Kod krivnje je osoba sposobnija distancirati se od sebe, za razliku od mogućnosti distanciranja kod srama. Osjećaj krivnje može biti okidač za pokajanje i za žaljenje, koji, ako budu prihvaćeni, mogu pobuditi u pojedincu konstruktivne i smislene promjene u smjeru ponovnoga dijaloga, obnavljanja odnosa, popravljanja, koji u konačnici mogu pridonijeti osobnom rastu, premda su bili potaknuti krivnjom koja im je u izvoru. Iz toga proistječe intenzivan osjećaj oslobađanja i mira ${ }^{62}$.

\section{Ususret krivnji i sramu}

Imajući u vidu dinamiku svake osobe i sve ono što to sa sobom uključuje, dakle misli, osjećaje, ponašanje, duhovnost, želimo ponuditi moguće puteve suočavanja s krivnjom i sramom.

Zanimljivo je primijetiti kako $S$. Tognacci ${ }^{63}$ pišući o sramu daje odmah na početku svoga članka jednu pozitivnu notu i krivnji i sramu te tako on piše: $\gg$ Sram, ali i stid, i još više osjećaj krivnje, dopušta nam da se suočimo sa sobom, da provjeravamo sebe same, da promišljamo, da se ispravljamo; naposljetku, recimo to bez velikog straha: pomaže nam da rastemo. $\ll \mathrm{Na}$ tragu toga stava želimo u ovom dijelu radu promišljati kako se suočavati sa sramom odnosno krivnjom kako bi služio na rast pojedincu, ali i zajednici. To smatramo prvim korakom, to jest pozitivno vrjednovanje svega onoga što čovjek u svom životu proživljava te na taj način ne želimo ignorirati, nego uvažavati ono što pojedinac u zajednici doživljava.

\subsection{SuOČAVANJE S KRIVNJOM}

Zasigurno je važno svakoj osobi pristupiti na jedinstven način s obzirom na sve karakteristike koje pojedinac sa sobom donosi, no pronalazeći načine kako se suočiti s krivnjom, predlažemo tri načina: davanje i otkrivanje smisla, igra i oproštenje.

\footnotetext{
${ }^{61}$ Isto, 91.

${ }^{62}$ S. TOGNACCI, Psihologija srama: glavni psihologijski i kulturološki vidovi, 463.

${ }^{63}$ Isto, 454.
} 
a) Davanje i otkrivanje smisla - Osoba koja svojem djelovanju daje smisao ravnajući se prema kriterijima dobrote, istine, ljepote, mnogo će lakše preuzimati odgovornost za te čine, a tamo gdje se preuzima odgovornost, manja je vjerojatnost za krivnju i osjećaj krivnje. Hodati životom istražujući zadnji smisao života, dati se u avanturu pronalaska onoga što donosi vremeniti i vječni život omogućava osobi djelovanje u većoj slobodi. Uvažavajući prostore duha, moguće je ublažavati krivnju pokušavajući pronaći koja je zadaća osobe u životu. Kada osoba pronađe svoju zadaću, tada će moći preuzeti i odgovornost, a gdje je odgovornost u slobodi, tamo je krivnja nikakva ili minimalna. U takvim situacijama čovjek sebe nadilazi. Rulla je specificirao mogućnosti samonadilaženja koje se ostvaruju na razini spoznaje, morala i ljubavi ${ }^{64}$. Samonadilaženje je još više moguće i ondje gdje osoba, kao što Frankl ${ }^{65}$ ističe, otkriva smisao. Prema Frankl osoba je pozvana otkriti smisao u životu jer će samo tako biti sposobna odgovoriti na egzistencijalni vakuum (das existentielle Vakuum) koji se upravo ondje javlja gdje nedostaje smisao, što dovodi do egzistencijalne frustracije ${ }^{66}$, do zatvorenosti u sebe. Nasuprot mogućnosti smisla čovjek je odgovoran te osjeća i doživljava ne samo potrebu postaviti si pitanje: Kakav smisao ima život?, što je jedno općenito pitanje, nego i postaviti si jedno daleko određenije i osobnije pitanje: Kakav smisao ima moj život? Na to je pitanje svatko pojedinačno pozvan odgovoriti imajući na pameti da dati odgovor na to pitanje »ne znači smatrati nečim morbidnim, nego da je to izraz čovjeka i onoga što je najhumanije $u$ njemu $\ll^{67}$. Odgovor koji čovjek daje na to pitanje okrenut je prema budućnosti koja se tada ne promatra kao nešto prijeteće, nego željno iščekujući. I u tome vidimo lijek za krivnju koja nema prostora u slobodi, samonadilaženju, odgovornosti i željenom iščekivanju osmišljene budućnosti.

b) Igra - Ovo promišljanje započinjemo Schillerovim riječima: »Jer, ako želimo odjednom izreći, čovjek se samo onda igra tamo gdje je u punom smislu riječi čovjek, a samo je tamo cjelovit čovjek, gdje se igra. ${ }^{68}$ Prema Schilleru čovjekova se dvostruka narav razvija upravo igrom, dok pod dvostrukom naravi on podrazumijeva misaono stremljenje prema ostvarenju u materijalnom životu te u duhovnoj potrebi za ljepotom. Krivnja i igra dva su suprotna elementa i uključuju u sebi različite elemente. Igra je osjećaj slobode, dok je krivnja osjećaj ukočenosti i zarobljenosti. Igra u sebi uključuje mogućnost biti više ili

\footnotetext{
${ }^{64}$ L. M. RULLA, Antropologija kršćanskog poziva, Zagreb, 2001., 109.

${ }^{65}$ V. E. FRANKL, Logoterapia e analisi esistenziale, E. Fizzotti (ur.), Brescia, 2005.

${ }^{66}$ V. E. FRANKL, Le radici della logoterapia, E. Fizzotti (ur.), Roma, 2000.

${ }^{67}$ V. E. FRANKL, Logoterapia e analisi esistenziale, 63.

${ }^{68}$ F. SCHILLER, Über die ästhetische Erziehung des Menschen, Leipzig, 2000.
} 
biti drukčije, a obje se mogućnosti upravo odnose na to da nadilaze trenutačno stanje jastva/sebstva. Biti više ili biti bolji očituje se i na raznim igrama. Za primjer možemo navesti olimpijske igre. Biti više ili biti drukčije predstavlja nam također i ideal koji je pred nama i koji ima značenje za nas te je osoba spremna taj ideal i slijediti. Ideali mogu jedno dijete dugo pratiti u njegovoj nutrini i obogaćivati njegov razvoj. Tamo gdje je skučen prostor za igru postoji opasnost da djeca slobodu, usmjerenje, kreativnost, divljenje, susretanje, osobnost, užitak, sreću, nagnuća koja su potaknuta unutarnjom motivacijom, kao i odmjeravanje s idealima, ne razvijaju dovoljno i da budu bitno uskraćeni za iskustvo. No nije bitna samo kvantiteta igre nego još i više njezina kvaliteta. Stoga kada govorimo o krivnji i o osjećaju krivnje, kao i o mislima koje prate onu osobu koja je kriva, ono što može pomoći u takvim situacijama jest pronaći način igre koji će osobi pomoći da se udalji od svoga začaranoga kruga misli te s određenim odmakom promatra samu sebe. Osjećaj krivnje može postati dio igre u koju osoba unosi ono što je opterećuje te daje jednu drugu dimenziju krivnji. Ovdje mislimo i na odrasle, a ne samo na djecu. Dječji liječnik i engleski psihoanalitičar D. W. Winnicott ${ }^{69}$ promatrao je igru kao stvarateljsko djelovanje u potrazi za sebstvom: Upravo u igri i samo u igri može se dijete i odrastao čovjek kreativno razvijati te uložiti cijelu osobnost. U kreativnom se razvijanju osoba otkriva i samoj sebi, kao i drugima. Igra omogućuje slobodan i autentičan susret $s$ drugim osobama, osjećaj ispunjenoga vremena te daljnjega osobnoga razvoja. Kultivirana međusobna ophođenja ljudi nisu neki oblik luksuza, nego nešto što temeljno doprinosi dostojanstvu ljudskoga bića ${ }^{70}$.

Tamo gdje postoje obveze i termini, očekivanja, a nedostaje prostora za igru, upravo se ondje lakše i razvija osjećaj krivnje jer nismo ispunili obveze, očekivanja, nismo se ponašali kao na zadatku. Osoba u igri lakše prihvaća odgovornosti i pravila koja postoje. Stoga igra nije samo slobodno provođenje vremena nego ima i svoj strukturirani element, koji tek omogućuje da bi igra bila svrsihodni$\mathrm{ja}^{71}$. Norme i pravila jesu općevažeća, dok u igri dolazi do izražaja autentičnost i individualnost. Netko tko se igra počinje se na vlastiti način izražavati i iznositi iz sebe sadržaj. Na taj način igra omogućava autentičnije izražavanje osobe, dok je krivnja često posljedica kršenja općevažećih normi, i građanskih i vjerskih.

c) Doživjeti oproštenje grijeha - U Katoličkoj Crkvi mnogi vjernici osjećaju se oslobođeni krivnje nakon sakramenta ispovijedi te taj čin pruža osobi potporu u

${ }^{69}$ D. W. WINNICOTT, Gioco e realtà, Roma, 1974.

${ }^{70}$ M. DARTSCH, Die Bedeutung des Spiels für den Menschen, u: Katholische Bildung 4(2013.), 176.184.

${ }^{71}$ Isto, 177. 
duhovnom i psihičkom rastu. Posljedice oproštenja grijeha u sakramentu ispovijedi imaju svoje višestruke pozitivne učinke, te stoga to može biti konkretan korak u pomoći osobama koje se osjećaju krivima, pod pretpostavkom, ipak, da nemaju krivu sliku Boga, što onda dovodi do pretjeranoga osjećaja krivnje, što smo već u našem radu naglasili. Vjera u Boga, Oca milosrđa, napose pomaže $u$ oslobađanju od krivnje (Iz 33, 24; Iz 40, 2; Lk 15,11-32).

\subsection{SUOČAVANJA SA SRAMOM}

Glavni problem, prema Tognacciu ${ }^{72}$, kada govorimo o sramu jest nesposobnost da se kod druge osobe izazove empatijska reakcija. To nam dakle govori kako je kod srama vrlo bitno empatijski suosjećati s osobom jer empatija oslobađa od osjećaja srama. Stoga prvi korak u suočavanju sa sramom, ali i s osjećajem krivnje, jest pokazivanje suosjećanja i razumijevanja, empatije prema osobi koja se srami ili koja se osjeća krivom ${ }^{73}$. Takav pristup jest usmjeren prema ponovnom uspostavljanju kontakta s osobom jer kod posramljene osobe dolazi do prekida veze s drugima, $s$ bližnjima, s Bogom. To smatramo središnjim zadatkom i procesom kod osoba koje trpe zbog prekomjernoga osjećaja srama.

Stoga ćemo proces uspostavljanja i održavanja kontakta sa sobom i drugima ocrtati u sljedećim četirima koracima: empatijsko propitivanje, usklađivanje, prisutnost i blagoslov.

a) Empatijsko propitivanje ${ }^{74}$ (inquiry) - Tim se propitivanjem dobronamjerno pristupa osobi koja se osjeća posramljeno ne bili se tim putem pažljivo, suosjećajno pomoglo osobi da sama istraži korijenje svojih misli, osjećaja, ponašanja i uvjerenja, da smisao istima i tako ponovno ude u kontakt sa svojim unutarnjim svijetom. To ujedno znači ući u iskustvo osobe koja se propituje i dati smisao cjelokupnoj trenutačnoj situaciji. Moguće je da će tako osoba upoznati svoje intrapsihičke sukobe te ožiljke iz svoga djetinjstva koji su doprinijeli odvajanju od vlastitoga životnoga iskustva. $U$ toj fazi potrebno je osobi pružiti sigurnost i potporu bez obzira kakvo bilo prošlo iskustvo osobe. Ostajući u kontaktu i empatijski propitujući fenomenološko iskustvo osobe koja se bori sa sramom, povećava se svijest o vlastitom sebstvu te također svijest o postojanju osjećaja,

\footnotetext{
${ }^{72}$ S. TOGNACCI, Psihologija srama: glavni psihologijski i kulturološki vidovi, 453.-477.

${ }^{73}$ Više o suosjećanju, empatiji i milosrđu u: D. VUKOVIĆ, J. BOŠNJAKOVIĆ, Empatija, suosjećanje i milosrđe: psihološke i teološke perspektive, u: Bogoslovska smotra 86(2016.)3, 731.-756.

${ }^{74}$ R. ERSKINE, R. L. TRAUTMANN, Methods of an Integrative Psychotherapy, u: Transactional Analysis Journal 26(1996.)4, 319.-320. Prva tri pojma preuzimamo od Erskine - Trautmann, te zbog toga ostavljamo na engleskom jeziku, s napomenom kako nam se inquiry u duhu hrvatskog jezika činilo najprimjerenije prevesti s empatijsko propitivanje.
} 
fantazija, unutarnjih doživljaja i onih procesa koji su doveli do prekida kontakta. U nazočnosti osobe koja harmonično i usklađeno slijedi i dobronamjerno prati posramljenu osobu događa se iskustvo ponovnoga vrjednovanja vlastite osobnosti te također vrjednovanja sebe kao relacijskoga/odnosnoga bića.

b) Usklađivanje $\mathrm{e}^{75}$ (attunement) - To je dvodijelni proces: počinje empatijom, to znači biti osjetljiv i poistovjećivati se s doživljajima druge osobe, potrebama i osjećajima te se nastavlja komunikacijom o tim doživljajima. Ono je više od empatijskoga razumijevanja te uključuje kinestetičko i emotivno doživljavanje drugoga. Poznajući ritam, emocije i iskustvo te nadilazeći empatiju, nudi recipročan i rezonirajući odgovor drugome. Usklađivanje je proces zajedništva i sjedinjujućega interpersonalnoga kontakta. Ono je ujedno poziv na održavanje uspostavljenoga kontakta. Usklađivanje se događa u razboritom odnosu $\mathrm{s}$ drugom osobom što uključuje emotivnu, kognitivnu i bihevioralnu dimenziju postojanja te, kao i empatijsko propitivanje, doprinosi osjećaju sigurnosti i povjerenja u drugoga, što je i pretpostavka trajnoga kontakta. To bi konkretno značilo kada se osoba osjeća žalosno da joj pristupamo suosjećajno. Ako je osoba ljuta, tada se prema njoj odnosimo s pažnjom, ozbiljnošću i odgovornošću te mogućim korektivnim djelovanjem, ispravljajući neka ponašanja. Onome tko je uplašen pristupamo s osjećajima i djelovanjima koja pružaju sigurnost i zaštitu. Ako je pak osoba radosna, tada dopunjavamo sjedinjujući interpersonalni kontakt recipročnim osjećajem životnosti i ugode postojanja ${ }^{76}$.

c) Uključenost (involvement) $)^{77}$ - Ona doprinosi da se prepoznavanjem, vrjednovanjem, normaliziranjem i prisutnošću smanjuju unutarnji obrambeni mehanizmi, u našem slučaju mehanizam srama. Prepoznavanje započinje usklađivanjem s osjećajima druge osobe, odnosnim potrebama, usklađivanjem ritma i razine razvojnoga funkcioniranja. Vrjednovanjem poručujemo osobi da se njezini osjećaji, obrambeni mehanizmi, fizički doživljaji ili oblici ponašanja odnose na nešto značajno u njezinu životnom iskustvu. Vrjednovanje spaja uzroke $s$ posljedicama te poštuje način na koji je osoba u kontaktu s drugima. Umanjuje mogućnost unutarnjega obezvrjeđivanja ili negiranja značajnosti osjećaja, fizičkih doživljaja, sjećanja i snova te podržava osobu u njezinu fenomenološkom iskustvu izražavanja. Nakana normaliziranja jest promijeniti način kako osoba kategorizira ili definira svoja unutarnja iskustva ili ponašanja te od perspektive koja je značajna za sram (nešto sa mnom nije u redu) doći do perspektive u kojoj osoba poštuje stare načine suočavanja s konfliktima. Važno je znati prepozna-

\footnotetext{
${ }^{75}$ R. ERSKINE, R. L. TRAUTMANN, Methods of an Integrative Psychotherapy, 320.

${ }^{76}$ Isto, 321.

${ }^{77}$ Isto, 324.-326.
} 
vati i imenovati arhaične poruke koje su roditelji ili neke druge bitne figure slali djetetu, a koje nisu vrjednovale iskustvo djeteta. Mnoga sjećanja, bizarna maštanja, noćne more, panični napadi i obrambeni mehanizmi bili su normalno suočavanje u nenormalnim situacijama. Važno je u takvim situacijama osobi reći da bi i mnogi drugi na jednak način reagirali. Nazočnost se odražava potporom, usklađenim odgovorom u verbalnoj i neverbalnoj komunikaciji s osobom s kojom smo u odnosu i koja je posramljena. Time se poštuje i proširuje integriranost te osobe. Nazočnost nadalje uključuje poštivanje osjećaja osobe, sposobnost ganuća pred njezinim doživljajima i stabilnoga odnosa koji uključuje sposobnost suočavanja sa strahovima, depresivnošću i ljutnjom pogođene osobe. Time pokazujemo odgovornost, suovisnost i dostupnost. Nazočnošću dajemo osobi do znanja kako je promjena moguća te izgrađujemo sigurnu međuljudsku povezanost. Više nego verbalna komunikacija nazočnost je zajedništvo između dvije osobe, ostvarenje trajnoga kontakta.

d) Blagoslov - Kada je netko blagoslovljen, tada je blagoslovljen cijeli njegov život, cijela osoba, te se osjeća prihvaćeno ${ }^{78}$. Osoba koja se srami ona se skriva jer ne želi biti viđena, dok u blagoslovu vidimo suprotan stav od skrivanja, a to je obasjavanje čovjeka Božjim licem. Ona osoba koja je posramljena zatvorena je u tišini, postaje nijema, glupa, nesposobna reći zašto se osjeća posramljeno. Ispovjediti da je netko posramljen oslobađa već jednim dijelom od srama. Sram se odnosi na spoznaju da je netko onakva osoba kakva ne želi biti te je također izraz tragičnoga otuđenja od samih sebe, kao i od svojih najbližih. To je ono što se događa npr. s osobama koje imaju poteškoća s alkoholom, drogom, pornografijom itd. Osobe se osjećaju posramljeno od sebe, ali otuđene i od drugih jer se žele skriti od njihovih pogleda, a često smatraju da drugi poznaju njihove tamne strane, te zbog toga i više izbjegavaju pogled drugih. Sram je povezan s osamljenošću i izolacijom, odbačenošću i tajnovitošću, pogreškama i manama. Nasuprot tomu blagoslov je izraz dobroga nad osobama i od osoba, a svoje najdublje utemeljenje ima u Bogu koji, stvarajući čovjeka, izriče kako je čovjek »veoma dobro « (Post 1, 31) stvorenje. Blagoslov znači prepoznavati vlastiti identitet u Bogu te time i vratiti osobi njezino dostojanstvo djeteta Božjega ( $\mathrm{Mk}$ $1,11)$. Blagoslovljena se osoba lakše prihvaća i ulazi ponovno u kontakt s Bogom, sa sobom is drugima te se otvara i prostor za nove mogućnosti u životu pojedine osobe, napose prihvaćanjem u ljubavi. Ljubav prema drugoj osobi, ali i prema samome sebi, doprinosi tome da čovjek ne vidi u drugome i u sebi tek

\footnotetext{
${ }^{78} \mathrm{Br}$ 6, 22-27: Bog reče Mojsiju: »Reci Aronu i njegovim sinovima: 'Ovako blagoslivljajte Izraelce govoreći im: Neka te blagoslovi Gospodin i neka te čuva! Neka te Gospodin licem svojim obasja, milostiv ti bude! Neka pogled svoj Gospodin svrati na te i mir ti donese!' Tako neka stavljaju moje ime nad sinove Izraelove, i ja ću ih blagoslivljati.«
} 
neku gotovu realnost, »nego također jednostavnu mogućnost, nešto što još ne postoji, ali je u nastajanju te može i treba postati $\ll .{ }^{79}$

\section{Zaključak}

Zaključujući naše promišljanje i suočavanje $s$ krivnjom i sramom, mogli bismo temeljno razlikovati krivnju i sram u dvama različitim pitanjima. Prvo se odnosi na osobu koja se osjeća krivom te će se ona pitati: Kako sam ja mogao to učiniti? Dok će se osoba koja se srami pitati: Kako sam ja to mogao učiniti ${ }^{80} \mathrm{I}$ krivnja i sram vrlo su složene stvarnosti, no ono što ih povezuje jest da su bitno povezani s relacijskom/odnosnom sposobnošću čovjeka. Čovjek živi od odnosa te zaključujemo kako sram ima dalekosežnije posljedice u prekidu odnosa, kontakta sa sobom, drugima i Bogom, te je stoga potrebnije više ga uzimati u obzir i otvarati nove horizonte promišljanja o sramu. Nemoguće je živjeti bez kontakta te, sažimajući naše promišljanje, otkrivamo važnost promocije međuljudskih odnosa koji uvažavaju moguće prekide i poteškoće u održavanju odnosa, no tim istim prekidima i poteškoćama daju smisao kako bi se ponovno uspostavio kontakt/relacija/odnos sa sobom, drugima i Bogom. Odnosi ispunjeni poštovanjem, autonomijom, uvažavanjem različitosti, razumijevanjem i suosjećanjem, opraštanjem i blagoslovom otvaraju nove prostore u suočavanju s krivnjom i sramom.

Svjesni načela kako više međusobno povezanih elemenata utječu na procese razvoja kod čovjeka, pa tako i na krivnju i sram, među kojima smo istaknuli važnost prvih figura odrastanja, zatim okruženje i vjerska uvjerenja, smatramo kako i u suočavanju s krivnjom i sramom treba uzeti više elemenata u obzir. Temeljni element jest razumijevati krivnju i sram kao mogućnost rasta i iskoraka iz nefunkcionalnih shema odnosa prema sebi, drugima i Bogu. Vrjednujući ih dakle kao mogućnost, a ne kao prijetnju i nemogućnost promjene, ističemo nužnost suradnje psihologije i teologije kako bismo pomogli čovjeku, shvaćenom kao otvoreni zadatak, u ostvarenju njega kao slobodnoga, odgovornoga i kreativnoga bića, sposobnoga za pogled prema naprijed. Krivnja i sram, napose ako ih osoba istovremeno proživljava, otežavaju svakodnevni obiteljski, poslovni i društveni život. Stoga ih je bitno razlikovati i pronalaziti načine suočavanja s njima, specifične za te obje obrađene stvarnosti, kako bi osoba bila sposobna obavljati svoje svakodnevne zadatke, ali isto tako i stvarati nove načine odnosa.

\footnotetext{
${ }^{79}$ V. E. FRANKL, Logoterapia e analisi esistenziale, 74.-87.

${ }^{80}$ J. P. TANGNEY, How does guilt differ from shame?, u: J. BYBEE (ur.), Guilt and Children, San Diego, 1998., 1.-17.
} 


\section{COPING WITH GUILT AND SHAME}

\section{Josip BOŠNJAKOVIĆ*}

Summary: To identify the feelings that make it difficult to establish relationships with others is important for the physical and spiritual well-being of a person, because when we do identify them and become aware of how they affect our lives, then we can change them in order to achieve fuller relationships with others.

To this end, in this paper we will analyze the complex feelings of guilt and shame, recognizing their potential for helping people to mature in their relationships with themselves, with others and with God. Both of these feelings are present from the beginning of the written word about man, but their topicality makes them significant for psychology and theology even today.

Both guilt and shame significantly affect the termination of relationships, which are recognized as a basic need of man as a social being, therefore it is important to see how can we help a person to restore, cultivate and improve their relationships. We have meditated on these two realities to offer concrete and specific proposals on how to address and integrate them.

Keywords: guilt, shame, isolation, relation/relationship, blessing.

* Josip Bošnjaković, Ph. D., Catholic Faculty of Theology in Đakovo, J. J. Strossmayer University of Osijek, P. Preradovića 17, 31400 Đakovo, Croatia; Catholic University of Croatia, Ilica 242, 10000 Zagreb, Croatia, jobosnjakovic@gmail.com 